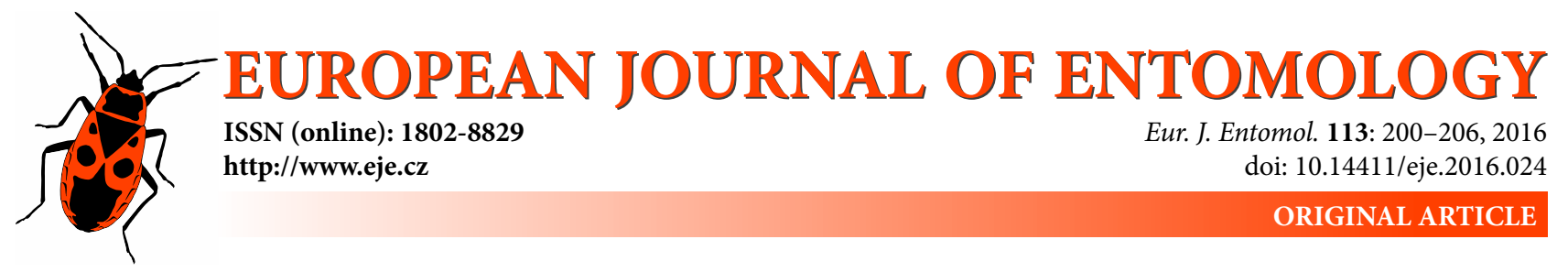

\title{
A little further south: Host range and genetics of the Northern pine processionary moth, Thaumetopoea pinivora (Lepidoptera: Notodontidae) at the southern edge of its distribution
}

\author{
José A. HÓdAR ${ }^{1}$, AnNa CASSEL-LUNDHAGEN ${ }^{2}$, ANdREA BATTISTI ${ }^{3}$ and STIg LARSSON ${ }^{2}$ \\ ${ }^{1}$ Departamento de Ecología, Facultad de Ciencias, Universidad de Granada, E-18071 Granada, Spain; e-mail: jhodar@ugr.es \\ ${ }^{2}$ Department of Ecology, Swedish University of Agricultural Sciences, Box 7044, SE-750 07 Uppsala, Sweden; \\ e-mails: anna.lundhagen@slu.se, stig.larsson@slu.se \\ ${ }^{3}$ DAFNAE-Entomologia, Agripolis, Universitá di Padova, Via Romea 16, 35020 Legnaro, Italy; e-mail: andrea.battisti@unipd.it
}

Key words. Lepidoptera, Notodontidae, Thaumetopoea pinivora, deforestation, genetic diversity, host shift, marginal woodlands, relict populations

\begin{abstract}
The Northern pine processionary moth, Thaumetopoea pinivora (Treitschke, 1834) shows a highly scattered distribution with fragmented populations across Europe. A previous study exploring the postglacial history of $T$. pinivora defined it as a cold-tolerant relict species and concluded that a progressive reduction of suitable habitats after the postglacial expansion from refugia in the southern Iberian peninsula best explained the distribution and genetic structure of populations of this species. However, recent records, both by us and others, challenge this view. Surprisingly, some of the newly found populations from southern Spain use black pine, Pinus nigra J.F. Arnold as a host plant despite the fact that the typical host of the species, Scots pine, Pinus sylvestris $L$. occurs in the area. We provide genetic data for one of these recently found southern populations where the larvae feed on $P$. nigra, and compare this with previously published data on individuals collected on $P$. sylvestris. This data reveals that populations from different host trees are no more genetically differentiated than populations sharing the same host plant. The findings of a wider diet breadth open the way to widen the search for the still unidentified glacial refugium of $T$. pinivora, and as such may contribute to a better understanding about how the species has spread across Europe.
\end{abstract}

\section{INTRODUCTION}

A currently accepted model on the relationship between distribution and abundance of living organisms posits that the more spatially widespread a species is the more abundant it is likely to be (Brown, 1984; Hanski et al., 1993). This pattern is thought to be explained by ecological specialization, where species with wider distributions are predominantly habitat generalists with a broad environmental tolerance (Brown, 1984; Lawton, 2000). There is, however, limited empirical support for this theory (Hanski et al., 1993), and there are examples of organisms that challenge this apparent rule (Louy et al., 2007; Habel \& Schmidtt, 2012; Cassel-Lundhagen et al., 2013).

The Northern pine processionary moth Thaumetopoea pinivora (Treitschke, 1834) (Lepidoptera: Notodontidae) is geographically widespread but locally rare (Cassel-Lundhagen et al., 2013). The latitudinal range of this species extends more than $5,000 \mathrm{~km}$ but is very fragmented. T. pinivora is found in coastal areas in Northern Europe around the Baltic Sea and inland in Germany and Poland (Koch, 1953; Larsson, 2006). In southern Europe it is restricted to few mountainous areas in France and Spain (Agenjo, 1941;
Montoya \& Robredo, 1972; Frérot \& Démolin, 1993; Cassel-Lundhagen et al., 2013). This species, thus, does not fit the definition of a so-called "generalist" species. While T. pinivora feeds on a very common coniferous host, the Scots pine Pinus sylvestris L., it appears to be restricted to widely spaced pine stands generally situated in harsh environments on poor soils, in which most trees are exposed to direct sunlight (Battisti et al., 2013). Furthermore, T. pinivora apparently has a limited ability to disperse, at least on a local scale (Ronnås et al., 2011).

The widely scattered populations and the limited dispersal capacity of T. pinivora pose an intriguing contradiction. A possible explanation is that the preferred habitat may have been more widespread in historical times (today's populations being effectively relict populations) or that the species is capable of long-distance dispersal (naturally or through a vector such as human agency). In a recent study combining ecological and genetic data from populations across its distribution range, Cassel-Lundhagen et al. (2013) suggested that slow-growing pine stands suitable for T. pinivora were more common in the past, at the time of the post-glacial colonization from its original refugia. 
They also suggested that since that time, such stands have disappeared from many regions due to climate change and, more recently, intensified forestry and agricultural activity (Stoate et al., 2001; Svenning, 2002; Rigling et al., 2013). In other words, a major reason for the modern day distribution of $T$. pinivora may due to human-driven fragmentation of a previously more continuous distribution of the host plant.

In June 2012, a small colony (four individuals) of $T$. pinivora was found in Cortijo Casimiro (Sierra de Baza, Granada, SE Spain). This record was exceptional for three reasons. Firstly, it was $375 \mathrm{~km}$ south of the southernmost record (Torre el Val, Teruel) listed by Cassel-Lundhagen et al. (2013). Secondly, the larvae were feeding on P. nigra J.F. Arnold, despite the fact that Sierra de Baza and the proximate Sierra Nevada maintain the two southernmost populations of $P$. sylvestris. According to the hypothesis of Cassel-Lundhagen et al. (2013), P. sylvestris was the only host. Thirdly, the site was at a lower elevation $(1,500 \mathrm{~m})$ than expected for a southern location, as the previous findings in central Spain were at 1,600-1,800 $\mathrm{m}$ (see Table 1 in Cassel-Lundhagen et al., 2013). A record from the more southerly situated Sierra Nevada-Sierra de Baza would be expected to be even higher, possibly around 1,600-2,200 $\mathrm{m}$, where the native subspecies of the Scots pine in Sierra Nevada and Sierra de Baza grows (P. sylvestris nevadensis D.H. Christ). Thus, this record challenged previous conclusions about the geographical distribution for the Northern processionary moth (Cassel-Lundhagen et al., 2013) and encouraged us to re-visit this matter.

In the present study, using high resolution molecular (DNA) markers, we initially genotyped individuals from this new locality and host plant, and compared the results with previous data in order to provide an updated picture of the newly found population in terms of its ecology and evolution. If the new location represents a part of the glacial refugia, we expected to find high levels of genetic diversity and unique genetic variation. On the other hand, if the sample represented a cryptic species that exclusively used $P$. nigra as host, then we expected, more especially if the split had occurred in ancient times, to find genotypes that differed significantly from those found on P. sylvestris. Secondly, we searched the recent published scientific literature concerning records of T. pinivora in Spain looking for other new and/or neglected records of the moth. Lastly, we attempted to physically validate any new location from this literature survey with regard to the ecological features until now known for the species. The ultimate goal was to evaluate to what extent the conclusions reached in CasselLundhagen et al. (2013) are consistent with the new records from southern Spain.

\section{MATERIALS AND METHODS}

\section{Collection of new samples}

On 25-26 May 2013, we (AB, JAH, SL) searched for additional T. pinivora colonies in the area surrounding the 2012 location in Cortijo Casimiro $\left(37^{\circ} 25^{\prime} \mathrm{N}, 2^{\circ} 51^{\prime} \mathrm{W}\right)$, totalling around 20 $\mathrm{h}$ of the most abundant tree species in the area, P. nigra. We also searched in a nearby $P$. sylvestris nevadensis stand at Prados del
Rey $\left(2,000 \mathrm{~m}, 37^{\circ} 22^{\prime} \mathrm{N}, 2^{\circ} 51^{\prime} \mathrm{W}\right)$. For every colony located, we sampled five individuals, which were immediately preserved in $96 \%$ ethanol.

\section{Genetic analysis of samples}

Nine highly variable genetic markers, i.e. microsatellite loci, and a 633 base pair long fragment of the second part of the mitochondrial DNA gene, cytochrome oxidase I (COI) were analysed as described in Cassel-Lundhagen et al. (2009), Ronnås et al. (2011) and Cassel-Lundhagen et al. (2013). Estimates of allelic richness (AR), unique allelic richness (UAR), and observed ( $\mathrm{Ho}$ ) and expected $(\mathrm{He})$ heterozygosity were calculated as described in Cassel-Lundhagen et al. (2013). Because there were indications of null alleles, we estimated pairwise $F_{S T}$ values using the so-called ENA method, as implemented in the FreeNA software (Chapuis \& Estoup, 2007); levels of significance were estimated by means of bootstrapping (1,000 replicates) using the same software. To analyse the population genetic structure we also ran a Bayesian clustering analysis on the microsatellite data as implemented in BAPS 6.0 (Corander \& Marttinen, 2006) to detect clustering of individuals, the method automatically estimating the number of clusters up to $K=12$, the number of locations analysed. This analysis is useful when the sample size is low. Grouping of individuals with no prior information about sampling site was set as model condition.

\section{Survey for new records}

Looking for new records, we surveyed the scientific literature, as well as internet sites of amateur entomologists. Due to the widespread presence of the much more abundant species Thaumetopoea pityocampa (Denis \& Schiffermüller, 1775) in Spain, we especially searched for records of the larval stage, information that usually also gave the host pine species from which these were collected, and we carefully checked the records pertaining to the adult moths. Whenever possible, we contacted the authors in order to confirm the reliability of these records and collected information about the characteristics of the locality, especially the pine species growing at the site.

Some of the localities were visited in order to describe their physical characteristics (topography and height above sea level, etc.). When this was not possible, and when the information from collectors was unavailable, we used the databases of the Spanish Geographical Institute (www.ign.es) to examine such characteristics. The Spanish Geographical Institute provides high-resolution aerial photographs, allowing a broad-scale survey of the environment where any particular record was found. Furthermore, they also provide aerial photographs of the same sites taken in the mid20th century (1957).

\section{RESULTS}

\section{New records in Cortijo Casimiro population}

During our search in Cortijo Casimiro in May 2013 we located six $T$. pinivora colonies, all individuals being third instar larvae, and all found feeding on P. nigra. We also identified old signs of feeding from previous years in some trees, which were undoubtedly caused by $T$. pinivora based on comparison with those of the current year, and excluding a possible confusion with those of $T$. pityocampa because the typical tents were missing. This suggests that the population at Cortijo Casimiro is small but stable. All colonies behaved in agreement with the known biological features for the species across Europe. No record was found for T. pinivora feeding on P. sylvestris in Prados del Rey. 
Table 1. Diversity estimates in all analysed locations of T. pinivora in Europe according to Cassel-Lundhagen et al. (2013) and, where appropriate, corrected for the new data from Cortijo Casimiro (CC, Spain). Results from CC are shown in bold. Allelic richness (AR) and unique allelic richness (UAR), the two most central estimates in this comparison, are corrected for variation in sample size.

\begin{tabular}{|c|c|c|c|c|c|c|c|c|c|c|}
\hline ID & Location & $\mathrm{N}$ & $\mathrm{AR}$ & UAR & UA & $\mathrm{Ho}$ & St err & $\mathrm{He}$ & St err & $F_{I S}$ \\
\hline G1 & Grynge & 20 & 2.95 & 0.11 & 0 & 0.600 & 0.066 & 0.563 & 0.060 & -0.067 \\
\hline ÖL & Oland & 28 & 2.58 & 0.09 & 0 & 0.427 & 0.058 & 0.487 & 0.058 & $0.125^{\star}$ \\
\hline G2 & Eksta & 22 & 2.83 & 0.12 & 0 & 0.561 & 0.045 & 0.555 & 0.049 & -0.010 \\
\hline G3 & Sudret & 72 & 2.97 & 0.16 & 2 & 0.540 & 0.068 & 0.550 & 0.060 & 0.017 \\
\hline $\mathrm{KA}$ & Kaliningrad & 79 & 3.47 & 0.47 & 5 & 0.588 & 0.076 & 0.606 & 0.078 & 0.030 \\
\hline $\mathrm{BO}$ & Bornholm & 10 & 3.07 & 0.21 & 0 & 0.522 & 0.080 & 0.533 & 0.082 & 0.022 \\
\hline $\mathrm{BE}$ & Berlin & 23 & 4.30 & 0.49 & 2 & 0.712 & 0.085 & 0.687 & 0.074 & -0.038 \\
\hline $\mathrm{HA}$ & France & 4 & 3.11 & 0.24 & 0 & 0.444 & 0.086 & 0.623 & 0.064 & $0.319^{*}$ \\
\hline GU & Guadarrama & 18 & 5.19 & 0.94 & 6 & 0.683 & 0.078 & 0.737 & 0.088 & $0.076^{*}$ \\
\hline MO & Mora de Rubielos & 49 & 5.81 & 0.91 & 16 & 0.766 & 0.050 & 0.834 & 0.057 & $0.082^{*}$ \\
\hline TO & Torre el Val & 16 & 5.58 & 0.77 & 4 & 0.776 & 0.052 & 0.835 & 0.045 & $0.072^{*}$ \\
\hline CC & Cortijo Casimiro & 6 & 4.70 & 0.95 & 1 & 0.574 & 0.056 & 0.771 & 0.055 & $0.274^{*}$ \\
\hline
\end{tabular}

$N$ - sample size; AR - allelic richness; UAR - unique allelic richness; UA - number of unique alleles; Ho - observed heterozygosity with standard error; $\mathrm{He}$ - expected heterozygosity with standard error; $F_{I S}$ - index indicating intra population deviations from Hardy-Weinberg expectations. * indicate values that differed significantly from expected/zero.

\section{mtDNA}

All six individuals in the sample from Cortijo Casimiro (CC, site 29 in Table 3) had the same mtDNA haplotype, identical to haplotype number 5 (GenBank accession number JX243019) in the study by Cassel-Lundhagen et al. (2013) and found only in Torre el Val (TO, Teruel, site 14). It was also the predominant haplotype in that population (4 out of 5 individuals bearing it). In all other locations analysed by Cassel-Lundhagen et al. (2013) haplotype number 1 was predominant.

\section{Microsatellites}

Five alleles identified as unique to a single population in Cassel-Lundhagen et al. (2013) were also found in this new location. Thus, the number of unique alleles was therefore two less in Mora de Rubielos (MO, site 12) and TO, and one less in Guadarrama (GU, sites 9-11) (all in Spain). One new unique allele was found in $\mathrm{CC}$.

The level of allelic richness and unique allelic richness (adjusted for differences in sample sizes) did not, however, differ between CC and the other locations in Spain. The highest number of alleles was therefore still found in populations at site $\mathrm{MO}$, while the unique allelic richness was equally high in three of the four Spanish locations (Table
1). The population at site $\mathrm{CC}$ was no more differentiated from the other locations than any of the other population pairs compared as illustrated in the pairwise $F_{S T}$ values and the Bayesian cluster analysis (Fig. 1, Table 2). Thus, the microsatellite data did not support the mtDNA data, which rather suggested a higher affinity of population $\mathrm{CC}$ with TO.

\section{New records in the literature survey}

Cassel-Lundhagen et al. (2013) reported subpopulations at 14 localities in Spain. The present study provides an additional 14, plus six recent records in previously known localities (Table 3). Most of the new records (Fig. 2) were from sites situated in between the previous southernmost record of Torre el Val and the new one of Cortijo Casimiro, with the exceptions of Cóms de Das (Girona, NE Spain, site 18) and Navaleno (Soria, Central Spain, site 16). Most of the records were from moths captured in light traps (Table 3). Given the flight capacity of the moth, especially the males, the capture site does not necessarily represent the habitat which the local $T$. pinivora population inhabits, so that all the conclusions referring to records of adults should be treated with caution.

Most of the new records were at the SE quadrant of the Iberian Peninsula, and almost all them were found only at

Table 2. Pairwise estimates of genetic differentiation between locations of T. pinivora in Europe according to Cassel-Lundhagen et al. (2013) plus the new locality of Cortijo Casimiro (CC, Spain) using an $F$-index $\left(F_{S T}\right)$ that compensate for possible effects of null alleles (the so-called ENA method). Estimates with bootstrap values larger than zero calculated for the $95 \%$ confidence intervals are shown in bold.

\begin{tabular}{|c|c|c|c|c|c|c|c|c|c|c|c|}
\hline pop & G1 & ÖL & G2 & G3 & KA & $\mathrm{BO}$ & $\mathrm{BE}$ & $\mathrm{HA}$ & GU & $\mathrm{MO}$ & TO \\
\hline ÖL & 0.113 & & & & & & & & & & \\
\hline G2 & 0.113 & 0.114 & & & & & & & & & \\
\hline G3 & 0.082 & 0.132 & 0.109 & & & & & & & & \\
\hline $\mathrm{KA}$ & 0.221 & 0.252 & 0.252 & 0.213 & & & & & & & \\
\hline BO & 0.311 & 0.372 & 0.351 & 0.289 & 0.228 & & & & & & \\
\hline $\mathrm{BE}$ & 0.158 & 0.188 & 0.202 & 0.164 & 0.106 & 0.135 & & & & & \\
\hline $\mathrm{HA}$ & 0.283 & 0.343 & 0.296 & 0.237 & 0.262 & 0.251 & 0.154 & & & & \\
\hline GU & 0.211 & 0.254 & 0.229 & 0.220 & 0.122 & 0.220 & 0.089 & 0.182 & & & \\
\hline MO & 0.186 & 0.218 & 0.202 & 0.199 & 0.143 & 0.154 & 0.085 & 0.105 & 0.039 & & \\
\hline TO & 0.187 & 0.225 & 0.198 & 0.197 & 0.161 & 0.198 & 0.108 & 0.108 & 0.056 & 0.005 & \\
\hline CC & 0.256 & 0.301 & 0.273 & 0.268 & 0.187 & 0.253 & 0.146 & 0.198 & 0.083 & 0.051 & 0.048 \\
\hline
\end{tabular}




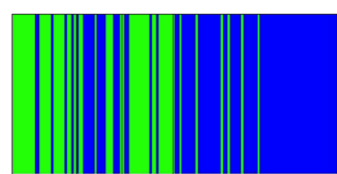

ÖL G01 G02
$\mathrm{GO} 3$

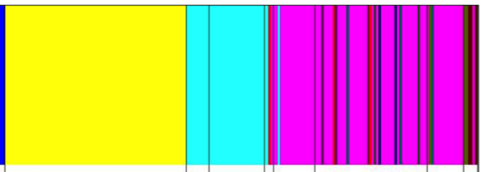

KA
BO BEHAGU MO TOCC
Fig. 1. Results from a Bayesian cluster analysis using microsatellite data of $T$. pinivora collected across its range. The number of optimal clusters $(K)$ were twelve when estimated in BAPS 6.0 (Corander \& Marttinen, 2006). The ID of locations are from Table 1.

mid elevation in plateaus or mountains (700-1,800 $\mathrm{m}$ except Cueva Úrsula, $450 \mathrm{~m}$, site 20), despite the fact that there were also pine woodlands at higher elevations. The majority of the new locations were in P. nigra forests, either alone or mixed with $P$. sylvestris, $P$. pinaster Aiton, and broadleaf trees (Holm oak, Quercus ilex L., Portuguese oak, Q. faginea Lamarck, Italian maple, Acer opalus Miller). There are two noteworthy exceptions, sites Cueva Negra (site 21) and Cueva Úrsula, at which the only pine species available was $P$. halepensis Miller (F. Lencina, pers. comm.). However, these records related to two fly- ing moths caught in a light trap, and in the case of Cueva Úrsula, only males were captured (Table 3).

Comparisons of old (1957) and recent (2010) aerial photographs of the locations show a continuous forest cover for all of them. The single exception is again Cueva Úrsula, although the 1957 pictures show forested areas only $2 \mathrm{~km}$ away from the location of capture.

\section{DISCUSSION}

From the new data as here collected, we show that $T$. pinivora is more widespread in Spain than previously reported by Cassel-Lundhagen et al. (2013). However, the new data support previous conclusions that $T$. pinivora distribution is highly fragmented as a consequence of habitat fragmentation. The main support for this conjecture is the presence of $T$. pinivora in SE Spain only at sites where pine forest cover has been permanent for the past 50 years or so. Spain underwent dramatic deforestations for centuries, and most of the present forested areas in Spain were planted during the second half of the 20th century (Vallejo

Table 3. Records of T. pinivora in Spain. Records 1-14 originate from Cassel-Lundhagen et al. (2013), while records 15-29 are new, although some of them coincide with the sites of former records. The altitude (a.s.l., in $m$ ) and the type of the record (Ph: $L-$ larva; $M-$ male moth caught at light trap; F - male and female moth caught at light trap; All - larva, male and female; U - not specified, probably moth) are also shown.

\begin{tabular}{|c|c|c|c|c|c|}
\hline$\#$ & Site & Province & a.s.I. & $\mathrm{Ph}$ & Reference \\
\hline 1 & El Escorial & Madrid & 1230 & $\mathrm{~F}$ & Agenjo, 1941 \\
\hline 2 & Pinares Llanos, Peguerinos & Ávila & 1050 & M & Agenjo, 1941 \\
\hline 3 & San Rafael & Segovia & 1450 & M & Agenjo, 1941 \\
\hline 4 & San Ildefonso de la Granja & Segovia & 1400 & $\mathrm{~F}$ & Agenjo, 1941 \\
\hline 5 & Tragacete & Cuenca & 1550 & MF & Agenjo, 1941 \\
\hline 6 & Peraleda Grande, Galapagar & Madrid & 860 & All & Montoya \& Robredo, 1972 \\
\hline 7 & Alto del León, Sa Guadarrama & Madrid & 1400 & All & Montoya \& Robredo, 1972 \\
\hline 8 & Alcalá de la Selva, Sa Gúdar & Teruel & 1450 & L & Frérot \& Demolin, 1993 \\
\hline 9 & Collado la Gasca, Sa Guadarrama & Madrid & 1620 & $\mathrm{~L}$ & G. Sánchez Peña \\
\hline 10 & Altos del León, Sa Guadarrama & Madrid & 1717 & $\mathrm{~L}$ & S. Larsson, A. Battisti \\
\hline 11 & Alto de Malagón, Sa Guadarrama & Madrid & 1560 & L & G. Sánchez Peña \\
\hline 12 & Mora de Rubielos & Teruel & 1700 & $\mathrm{~L}$ & S. Larsson, A. Battisti \\
\hline 13 & Sierra de Gúdar & Teruel & 1590 & $\mathrm{~L}$ & G. Sánchez Peña \\
\hline 14 & Torre el Val, Javalambre & Teruel & 1768 & $\mathrm{~L}$ & S. Larsson, A. Battisti \\
\hline$=5$ & Umbría de la Virgen, Tragacete & Cuenca & 1310 & M & Ortiz et al., 2012 \\
\hline 15 & Cercedilla & Madrid & - & M & Agenjo, 1958 \\
\hline$=1$ & no further details & Madrid & - & $\mathrm{U}$ & Gómez-Bustillo, 1977 (= Agenjo, 1941?) \\
\hline$=1$ & no further details & Madrid & - & U & Gómez-Bustillo, 1978 (= Agenjo, 1941?) \\
\hline$=13$ & Sierra de Gúdar & Teruel & - & $U$ & Redondo, 1990 \\
\hline 16 & Navaleno & Soria & 1050 & U & Redondo, 1976 \\
\hline$=16$ & no further details & Soria & - & $U$ & Gómez-Bustillo, 1979 \\
\hline 17 & Montes Universales & Teruel & 1400 & $U$ & Gómez-Bustillo, 1979 \\
\hline 18 & Cóms de Das, Cerdanya & Girona & 1800 & M & Pérez de Gregorio \& Redondo, 1994 \\
\hline 19 & Monte Alto Negro, La Yesa & Valencia & 1160 & $\mathrm{~L}$ & López-Sebastián et al., 2002 \\
\hline 20 & Cueva Úrsula, Villamalea & Albacete & 450 & M & Lencina et al., 2011 \\
\hline 21 & Cueva Negra, Potiche-Ayna & Albacete & 700 & MF & Lencina et al., 2011 \\
\hline 22 & Fuente de la Guitarra, Riópar & Albacete & 960 & M & Lencina et al., 2011 \\
\hline 23 & Pista del Calar, Riópar & Albacete & 1100 & MF & Lencina et al., 2011 \\
\hline 24 & Barranco Toromocho, Peñascosa & Albacete & 1300 & MF & F. Lencina, pers. comm. \\
\hline 25 & Arroyo de Santiago, Huéscar & Albacete & 1480 & $\mathrm{~F}$ & Lencina et al., 2011 \\
\hline 26 & Cerro Juan Tomás, Sa Guillimona & Granada & 1690 & M & F. Lencina, pers. comm. \\
\hline 27 & Cortijo Alguacil, P. D. Fadrique & Granada & 1400 & $\mathrm{~L}$ & M.A. Gómez de Dios, pers. comm. \\
\hline 28 & Casa Valero, Puebla D. Fadrique & Granada & 1400 & $\mathrm{~L}$ & M.A. Gómez de Dios, pers. comm. \\
\hline 29 & Cortijo Casimiro, Sa Baza & Granada & 1490 & $\mathrm{~L}$ & A. Battisti, J.A. Hódar, S. Larsson \\
\hline
\end{tabular}




\section{Pinus sylvestris}
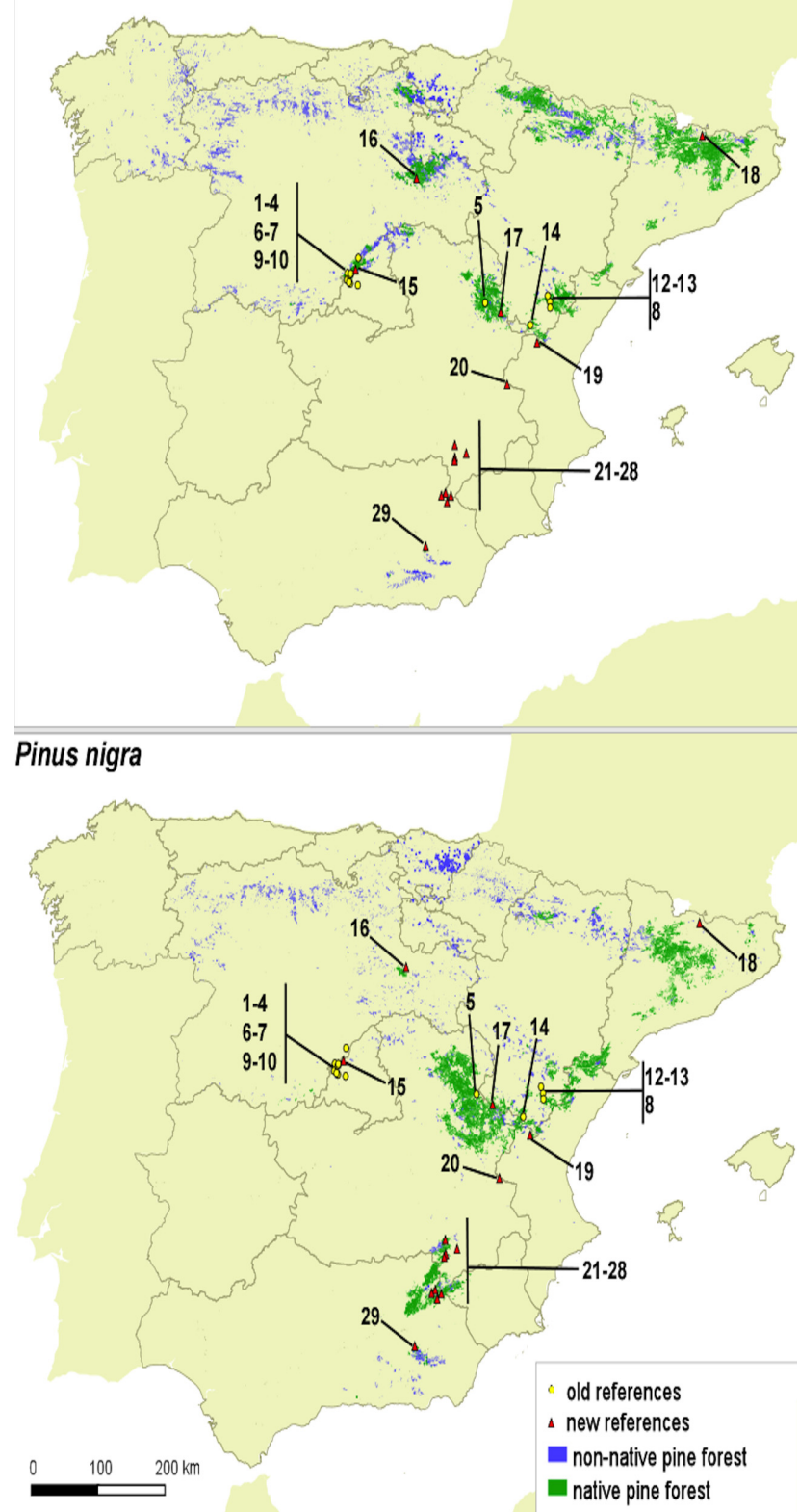

Fig. 2. Location of records of T. pinivora in Spain published in Cassel-Lundhagen et al. (2013) (yellow dots) and new locations (red triangles) in relation to the distribution of the main autochthonous (green) and planted (blue) woodlands of Pinus sylvestris (upper panel) and Pinus nigra (lower panel). Maps with the woodland distribution were kindly supported by the Spanish network on $\mathrm{Ge}$ netics and Conservation of Forest Resources (GENFORED). The numbers of locations are from Table 3 .

et al., 2003). Thus, the presence of T. pinivora in areas with forest cover in 1957 supports the view that they are relict populations, in agreement with the habitat loss and fragmentation hypothesis of Cassel-Lundhagen et al. (2013). In other words, the scattered locations in SE Spain are not the result of recent colonization, but rather represent established populations that have become isolated as a consequence of massive deforestation for purposes of wood harvest, livestock and arable cultivation. However, even though less likely, the possibility that the current locations were in fact the only ones existing suitable for $T$. pinivora cannot be excluded. The lack of human exploitation in $T$. pinivora areas would thus account for the distribution of the species, although a more detailed genetic study would be necessary to further clarify the demographic history of the species and add support to this contention.

The new genetic data does not take us closer to finding the missing location of the glacial refugium of the moth in Europe, but the information clearly indicates that larvae feeding on $P$. nigra do not represent a cryptic species. The mitochondrial haplotype identified (these results) was identical to one population analysed by Cassel-Lundhagen et al. (2013) and found in the Teruel region (Torre el Val). This likely means that these populations share an evolutionary history that differs from populations at the other locations. However, the haplotype diversity does not show that the Cortijo Casimiro population has an older history than that of any of the other populations studied and nuclear (microsatellite) genetic diversity was similar to those from central Spain. This should, however, naturally be seen as a preliminary conclusion due to the small sample size.

The conclusions of Cassel-Lundhagen et al. (2013) on the location of the glacial refugium were based on $P$. sylvestris as the main host for $T$. pinivora. Although $P$. sylvestris is the only host of T. pinivora in Central and Northern Europe, and in some localities in central Spain, this is not the case in SE Spain. Here the species has rather been found in areas dominated by P. nigra or P. halepensis, and T. pinivora has been found to feed on $P$. nigra rather than on $P$. sylvestris. Hence it is uncertain whether the glacial refugium involved relict populations on $P$. sylvestris, on $P$. nigra, or on both. The link between $P$. nigra and the southernmost populations of $T$. pinivora argues that $P$. nigra may actually be the host in the still unidentified refugium. If so, T. pinivora probably shifted to $P$. sylvestris before moving northwards. The lack of $T$. pinivora records on the southernmost populations of $P$. sylvestris agree with this view.

Conversely, more data are required from sites in which $P$. halepensis seems to be the only host available [an apparently similar shift in host has recently been described for the Spanish moon moth, Graellsia isabellae (Graëlls, 1849 ) in a restricted population at Sierra de María (Almería, SE Spain, Ibáñez-Gázquez et al., 2008; also M. Paracuellos and J.C. Nevado, pers. comm.)]. In the case of the Eastern processionary moth, this possibility requires confirmation, however, since most of the new records were based on adults, and therefore the possibility of populations remaining on isolated trees of $P$. nigra or $P$. sylvestris cannot be ruled out. Adult moths, especially males, can fly several kilometres, so that the place of capture may not give correct information as to the true habitat that the population inhabits.

Another issue concerns the suggestion by Cassel-Lundhagen et al. (2013) that the further south the population resides the higher its altitude. While the highest records in central and northern Spain relate to moths captured between 1,500-1,800 $\mathrm{m}$, at the southernmost edge of the range all the records were for moths found at 700-1,500 m. This was despite the fact that suitable hosts are available in 
many mountain ranges well above this elevation (and, in the case of Sierra de Baza, these woodlands all comprise of P. sylvestris). One possibility is that the altitudinal distribution of T. pinivora in SE Spain is not determined solely by climate and host plant but also by other factors as yet still unknown.

In conclusion, $T$. pinivora shows a wider host range than previously documented. Until now Scots pine, P. sylvestris, was considered to be almost the exclusive host, whereas our findings suggest that $P$. nigra is more important than previously thought. Especially intriguing is the finding that the species was found on this host at a relatively low elevation at the southern geographic range edge. These new findings open the way to a better understanding of the geographic distribution of the insect, and will affect how entomologists subsequently search for the still unidentified glacial refugium, assuming it exists.

ACKNOWLEDGEMENTS. We thank P. Faluke, T. Fariño, M.Á. Gómez de Dios (Migüi), F. Lencina, J.C. Nevado, M. Paracuellos, C.W. Plant and J. Pérez-López for invaluable information on several new records relating to the distribution of T. pinivora; A. Boato, A. Lázaro and R. Ruiz-Puche for assistance during field work; and L. Torres-Muros for help with the design of Fig. 2. Fruitful discussions and data from J.C. Linares and M. Simonato, and suggestions by two anonymous referees along with editorial comments by D. Nesbitt and H.D. Loxdale, much improved the manuscript. The Andalusian Environmental Council, Junta de Andalucía, and the Direction of the Sierra de Baza and Natural Park provided permission to work in Cortijo Casimiro. The study was supported by projects CLAVINOVA (MICINN, P10RNM6734) to JAH, the University of Padova to AB, and the Swedish University of Agricultural Sciences to SL and ACL. Author contributions: JAH found the record at Casimiro; JAH, AB and SL designed the study and collected new samples in the field; ACL performed the genetic analysis; JAH reviewed the literature and arranged the maps; and JAH, ACL, AB and SL wrote the paper.

\section{REFERENCES}

Agenjo R. 1941: Monografía de la familia Thaumetopoeidae. EOS 18: 69-130.

Agenjo R. 1958: Captura de Thaumetopoea pinivora (Treitschke, 1832) en Cercedilla, provincia de Madrid. - Bol. Serv. Plagas For. 2: 59-63.

Battisti A., Marini L., Pitacco A. \& Larsson S. 2013: Solar radiation directly affects larval performance of a forest insect. - Ecol. Entomol. 38: 553-559.

Brown J.H. 1984: On the relationship between abundance and distribution of species. - Am. Nat. 124: 255-279.

Cassel-Lundhagen A., RonnÅs C. \& Frauenfelder N. 2009: Characterization and cross-amplification of 13 microsatellite loci in the northern pine processionary moth, Thaumetopoea pinivora (Lepidoptera: Notodontidae). - Mol. Ecol. Res. 9: 1074-1075.

Cassel-Lundhagen A., Ronn̊̊s C., Battisti A., Wallén J. \& LARSSON S. 2013: Stepping-stone expansion and habitat loss explain a peculiar genetic structure and distribution of a forest insect. - Mol. Ecol. 22: 3362-3375.

Chapuis M.-P. \& Estoup A. 2007: Microsatellite null alleles and estimation of population differentiation. - Mol. Biol. Evol. 24: 621-631.
Corander J. \& MartTinen P. 2006: Bayesian identification of admixture events using multi-locus molecular markers. - Mol. Ecol. 15: 2833-2843.

Frérot B. \& Démolin G. 1993: Sex pheromone of processionary moths and biosystematic considerations within the genus Thaumetopoea (Thaumetopoeidae: Thaumetopoeinae). Boll. Zool. Agr. Bachicolt. 25: 33-40.

Gómez-Bustillo M.R. 1977: Los Thaumetopoeidae (Aurivilius, 1891) de la Península Ibérica: nociones de sistemática, ecología e importancia económica de la familia. — SHILAP 5: 283-290.

Gómez-Bustillo M.R. 1978: Los Thaumetopoeidae (Aurivilius, 1891) de la Península Ibérica: nociones de sistemática, ecología e importancia económica de la familia. - SHILAP 6: $113-123$.

Gómez-Bustillo M.R. 1979: Mariposas de la Península Ibérica (Heteróceros II). Ministerio de Agricultura-ICONA, Madrid, pp. 54-69.

Habel J.C. \& Schmitt T. 2012: The burden of genetic diversity. - Biol. Conserv. 147: 270-274.

Hanski I., Kouki J. \& HalkKa A. 1993: Three explanations of the positive relationship between distribution and abundance of species. In Ricklefs R.E. \& Schluter D. (eds): Species Diversity in Ecological Communities. Historical and Geographical Perspectives. The University of Chicago Press, Chicago, London, pp. 108-116.

IbÁÑ̃ez Gázquez S., Nevado Ariza J.C. \& Ylla Ullastre J. 2008: Graellsia isabelae (Graells, 1849), una nueva especie para la fauna lepidopterológica de Almería (España) (Lepidoptera: Saturniidae). - SHILAP 36: 427-430.

Косн M. 1953: Zur Biologie des Kiefernprozessionsspinners, Thaumetopoea pinivora Tr. - Beitr. Entomol. 3: 423-427.

LARSSON S. 2006: Mass occurrence of the northern pine processionary moth Thaumetopoea pinivora on southern Gotland. Entomol. Tidskr. 127: 1-7.

Lawton J.H. 2000: Community Ecology in a Changing World. International Ecology Institute, Oldendorf/Luhe, $227 \mathrm{pp}$.

Lencina F., Albert F., Aistleitner U. \& Aistleitner E. 2011: Fauna lepidopterológica de Albacete. Catálogo de macroheteróceros (III): Cossoidea, Zygaenoidea, Lasiocampoidea, Bombycoidea y Noctuoidea (parte). - Sabuco, Rev. Estud. Albacet. 8: 153-186.

López-Sebastián E., Selfa J. \& Juan-Martínez M.J. 2002: Acerca de la presencia de Thaumetopoea pinivora (Lepidoptera, Notodontidae) en la provincia de Valencia. - Bol. Asoc. Esp. Entomol. 26: 140-142.

Louy D., Habel J.C., Schmitt T., Assmann T., Meyer M. \& MülLER P. 2007: Strongly diverging population genetic patterns of three skipper species: the role of habitat fragmentation and dispersal ability. - Cons. Genet. 8: 671-681.

Montoya R. \& Robredo F. 1972: Thaumetopoea pinivora, Tr. La procesionaria de verano. - Bol. Est. Centr. Ecol. 1: 43-56.

Ortiz A.S., Garre M., Guerrero J.J., Rubio R.M. \& Calle J.A. 2012: Los Noctuoidea del Parque natural de la Serranía de Cuenca (España) (Insecta: Lepidoptera). — SHILAP 40: 245277.

Pérez de Gregorio J.J. \& Redondo V.M. 1994: Thaumetopoea pinivora Treitschke, 1834, Thaumetopoeidae nou per a la fauna de Catalunya (Lepidoptera). - Ses. Entomol. ICHN SCL (Barcelona) 8: 87-90

REDONDO V.M. 1976: Nuevas capturas de lepidópteros de los alrededores de Zaragoza. — SHILAP 16: 357.

REDondo V.M. 1990: Las mariposas y falenas de Aragón: Distribución y catálogo de especies. Diputación General de Aragón, Colección Estudios y Monografías 14, Zaragoza, Spain, 226 pp. 
Rigling A., Bigler C., Eilmann B., Feldmeyer-Christe E., Gimmi U., Ginzler C., Graf U., Mayer P., Vacchiano G., Weber P., Wohlgemuth T., Zweifel R. \& Dobbertin M. 2013: Driving factors of a vegetation shift from Scots pine to pubescent oak in dry Alpine forests. - Global Change Biol. 19: 229-240.

Ronnås C., Cassel-Lundhagen A., Battisti A., Wallén J. \& LARSSON S. 2011: Limited emigration from an outbreak of a forest pest insect. - Mol. Ecol. 20: 4604-4617.

Stoate C., Boatman N.D., Borralho R.J., Carvalho C.R., De SNOO C.R. \& EDEN P. 2001: Ecological impacts of arable intensification in Europe. - J. Environ. Manag. 63: 337-365.
SvenNING J.C. 2002: A review of natural vegetation openness in north-western Europe. - Biol. Conserv. 104: 133-148.

Vallejo R., Cortina J., Vilagrosa A., Seva J.P. \& Alloza J.A. 2003: Problemas y perspectivas de la utilización de leñosas autóctonas en la restauración forestal. In Rey-Benayas J.M., Espigares T. \& Nicolau J.M. (eds): Restauración de ecosistemas mediterráneos. UAH, Alcalá de Henares, pp. 11-42.

Received March 26, 2015; revised and accepted December 21, 2015 Published online February 5, 2016 